\title{
Effect of Fruit Size on the Ripening of Edward Mangoes $^{1}$
}

\author{
Hugo L. Cancel and Teresa Garcia de Pérez ${ }^{2}$ \\ ABSTRACT
}

Edward mangoes having a selected range of diameters and in green-ripe stage were submitted to controlled storage. Green-ripe fruits with their greater diameter 3 in or more ripened into good quality fruits when stored at $70^{\circ} \mathrm{F}$ $\left(21^{\circ} \mathrm{C}\right)$ and $85-90 \%$ relative humidity.

\section{INTRODUCTION}

The quality and storage life of the fruits which are used for the fresh market depend on the variety, the stage of maturity and the storage conditions. Different methods have been used for harvesting mangoes in order to improve their quality.

A decision on the proper ripeness stage of mangoes must be made since the fully ripe mangoes are very poor shippers. It has also been found that tree-ripened mangoes are inferior in aroma to the fruits that ripen after picking (6).

Studies on the physical indices for harvesting mangoes at different maturity and ripeness levels have included weight, color, and other physical measurements (2).

Several investigators have examined the chemical composition of ripe and unripe mangoes. During ripening there is a breakdown of starch to sugars and a decrease in acidity. Soule and Harding (5) noticed that there are rapid changes occurring during the first 3 or 4 days of ripening: total soluble solids increased and starch disappeared completely.

According to different investigators, the storage temperature required for ripening mangoes varies from 21 to $27^{\circ} \mathrm{C}\left(70^{\circ}\right.$ to $\left.81^{\circ} \mathrm{F}\right)$.

This research was undertaken to study the ripening behavior of mangoes cv. Edward of different diameters submitted to controlled conditions of temperature and relative humidity.

\section{MATERLALS AND METHODS}

Mangoes of the Edward variety harvested at the Fortuna Substation on the southern coast of Puerto Rico were used.

Sound fruits showing a peel of a deep green color were sorted for size and treated in hot water at $51^{\circ} \mathrm{C}\left(124^{\circ} \mathrm{F}\right)$ to control anthracnose (4). The treated fruits were blotted and air dried at ambient conditions.

\footnotetext{
' Manuscript submitted to Editorial Board November 16, 1978.

${ }^{2}$ Assistant Food Technologist and Research Assistant, respectively, Food Technology Laboratory, Agricultural Experiment Station, Mayagüez Campus, University of Puerto Rico, Río Piedras, P.R.
} 
Fruits were graded according to size as follows: No. 1, fruits with a diameter less than $2^{1 / 2}$ in; No. 2, fruits larger than $2^{1 / 2}$ in but smaller than 3 in; No. 3 fruits larger than 3 in but smaller than $3 \frac{1}{2}$ in; No. 4 , fruits larger than $3^{1 / 2}$ in.

For ripening studies, fruits of sizes 2,3 and 4 were used. The fruits were stored in an environmental chamber at $70^{\circ} \mathrm{F}\left(21^{\circ} \mathrm{C}\right)$ with relative humidity ranging from 85 to $90 \%$.

At periodic intervals the fruits were classified according to the following stages of ripening as judged from the color of the peel: In A, green, the peel was a deep green color; B, green-yellow, the peel was turning yellow but more than $50 \%$ was green; C, yellow-green, more than $50 \%$ was yellow but with green areas; D, yellow, peel was yellow with no green.

TABLE 1.-Changes during the ripening stage of different sizes of Edward mangoes stored at $70^{\circ} \mathrm{F}$ and $85-90 \%$ relative humidity

\begin{tabular}{|c|c|c|c|}
\hline \multirow{2}{*}{ Ripening stage } & \multicolumn{3}{|c|}{ Storage time-days } \\
\hline & 5 & 9 & 15 \\
\hline & \multicolumn{3}{|c|}{ Fruits at each ripening stage } \\
\hline & $\%$ & $\%$ & $\%$ \\
\hline & \multicolumn{3}{|c|}{ Size No. 2} \\
\hline A-green & 70.0 & 3.8 & 0.0 \\
\hline $\mathrm{B} \longrightarrow>50 \%$ green & 25.0 & 66.5 & 3.5 \\
\hline $\mathrm{C}->50 \%$ yellow & 5.0 & 24.5 & 27.0 \\
\hline \multirow[t]{2}{*}{ D-yellow, fully ripe } & 0.0 & 3.8 & 69.5 \\
\hline & \multicolumn{3}{|c|}{ Size No. 3} \\
\hline A. & 62.6 & 2.4 & 0.0 \\
\hline B & 25.8 & 62.6 & 0.6 \\
\hline $\mathrm{C}$ & 11.0 & 23.3 & 2.5 \\
\hline \multirow[t]{2}{*}{$\mathrm{D}$} & 0.6 & 11.7 & 96.9 \\
\hline & \multicolumn{3}{|c|}{ Size No, 4} \\
\hline A & 55.6 & 0.0 & 0.0 \\
\hline B & 22.2 & 44.4 & 0.0 \\
\hline $\mathrm{C}$ & 22.2 & 22.3 & 0.0 \\
\hline $\mathrm{D}$ & 0.0 & 33.3 & 100.0 \\
\hline
\end{tabular}

At the same intervals, samples of each fruit size were analyzed for starch, total and reducing sugars, and total acidity. Starch was determined by the method of Carter and Neubert (1); total and reducing sugars by the Lane and Eynon volumetric method (3). Total acidity was determined according to A.O.A.C. official procedures (3). Samples of each size were submitted to organoleptic evaluation on a six-point scale to determine overall sample quality: 6 -like very much; 1 -dislike extremely.

\section{RESULTS AND DISCUSSIONS}

Table 1 shows the percentage of fruit of each size at four stages of ripening after storage for 5, 9 and 15 days. Irrespective of fruit size, an 
increase in the percentage of ripe fruit was observed to take place during storage. After storage for 15 days, the percentage of fruits which had attained a fully ripe stage (stage D) was higher in fruits of sizes 3 and 4 than in size 2. At this time, in fruits of size 2 there was a considerable amount of $\mathrm{B}$ and $\mathrm{C}$ ripeness, while in size $3,96.9 \%$; and all the fruits of size 4 were in stage D. Thus in the Edward mango there seems to be a correlation between the size and the ripening pattern when stored under controlled conditions. In this study fruits which ripened satisfactorily after storage for 15 days ranged in size from 3 in or greater in diameter.

TABLE 2.-Chemical analysis of stored Edward mangoes of different sizes and at different ripeness stages

\begin{tabular}{|c|c|c|c|}
\hline \multirow{2}{*}{ Ripeness stage } & \multicolumn{3}{|c|}{ Fruit size } \\
\hline & 2 & 3 & 4 \\
\hline & \multicolumn{3}{|c|}{ Starch $(\%)$} \\
\hline A-green & 7.36 & 9.26 & 13.79 \\
\hline $\mathrm{B} \longrightarrow>50 \%$ green & 2.23 & 2.08 & 1.21 \\
\hline $\mathrm{C} \rightarrow>50 \%$ yellow & $<1.00$ & $<1.00$ & $<1.00$ \\
\hline \multirow{2}{*}{ D-yellow, fully ripe } & $<1.00$ & $<1.00$ & $<1.00$ \\
\hline & \multicolumn{3}{|c|}{ Total sugars (\%) } \\
\hline A & 2.56 & 3.03 & 3.59 \\
\hline B & 11.78 & 11.79 & 10.50 \\
\hline $\mathrm{C}$ & 13.25 & 16.13 & 15.45 \\
\hline \multirow[t]{2}{*}{$\mathrm{D}$} & 14.45 & 15.60 & 15.75 \\
\hline & \multicolumn{3}{|c|}{ Reducing sugars (\%) } \\
\hline A & 1.86 & 2.23 & 1.89 \\
\hline $\mathrm{B}$ & 3.14 & 3.80 & 4.04 \\
\hline $\mathrm{C}$ & 3.40 & 3.78 & 3.80 \\
\hline \multirow[t]{3}{*}{$\mathrm{D}$} & 3.35 & 3.90 & 3.92 \\
\hline & \multicolumn{3}{|c|}{ Acidity } \\
\hline & \multicolumn{3}{|c|}{ ( $m g$ of citric acid/100 g sample) } \\
\hline A & 2.86 & 2.46 & 1.94 \\
\hline $\mathrm{B}$ & 1.40 & 1.29 & 1.30 \\
\hline $\mathrm{C}$ & 0.50 & 0.35 & 0.25 \\
\hline $\mathrm{D}$ & 0.29 & 0.21 & 0.20 \\
\hline
\end{tabular}

Table 2 shows the changes in starch, total and reducing sugars, and acidity percentage during storage. In all three sizes at the green stage (ripeness A) the starch content increased as the size of the fruit increased. There was a slight increase in total sugars among the three different sizes, while the acidity decreased as fruit size increased. During ripening, the starch is converted to sugars, the total sugar content reaching an average of $15 \%$ for sizes 3 and 4 at stages $C$ and D. The acidity in all sizes decreased as the fruit ripened. 
For organoleptic evaluation, only fruit at ripeness stage C or D was used. Fruit at stage B had an astringent taste and poor eating quality; it was not included in the test. Table 3 shows that at ripeness stage $\mathrm{C}$, the sensory rating increased with the size of the fruit. At stage D, fruits of sizes 3 and 4 received higher ratings than those of size 2. It was also observed that fruits of size 2 shrivelled during storage and also developed a duller yellow color than sizes 3 and 4 .

The results show that when Edward mangoes are harvested at a green stage with the fruit's diameter 3 in or greater, the fruit can be ripened under controlled conditions. Mangoes thus ripened were of excellent quality.

TABLE 3.-Average response of tasters on the general quality of mangoes, using a 6point hedonic scale ${ }^{1}$

\begin{tabular}{rccc}
\hline \multirow{2}{*}{ Apparent ripeness } & \multicolumn{3}{c}{ Fruit size } \\
\cline { 2 - 4 } & 2 & 3 & 4 \\
\hline C- $>$ 50\% yellow & 3.0 & 5.0 & 5.6 \\
D-yellow, fully ripe & 4.0 & 5.8 & 5.8 \\
\hline
\end{tabular}

${ }^{1}$ 6-like very much; 1-dislike extremely.

\section{RESUMEN}

La calidad del mangó depende en gran medida de la etapa de crecimiento y la época de recolección. En este estudio se observó la relación que pueda haber entre el diámetro mayor de la fruta de la cultivar Edward con el proceso de maduración. Las frutas se seleccionaron por su tamaño y madurez aparente; solo las de color verde, pero de distintos tamaños. Estas se almacenaron a $70^{\circ} \mathrm{F}\left(21^{\circ} \mathrm{C}\right)$ y $85-90 \%$ humedad relativa para observar su comportamiento durante el almacenamiento.

Las frutas cuyo diámetro mayor era de 3 pulgadas o más maduraron bien y eran de buena calidad. Las frutas de menos de 3 pulgadas maduraron en menor proporción. En las pequeñas se observaron algunos signos de baja calidad, tales como el arrugamiento de la piel y el desarrollo de un color amarillo opaco.

Los análisis químicos demuestran que hay un incremento en el contenido en almidón a medida que aumenta el diámetro de la fruta. Este se hidroliza en azúcares rápidamente a medida que progresa la madurez. Al mismo tiempo la acidez disminuye, por lo cual el sabor es más agradable.

\section{LITERATURE CITED}

1. Carter, J. H. and Neubert, A. M., 1954. A rapid determination of starch in apples, J. Agri. Food Chem. 2 (21): 70-2. 1960.

2. Krishnamurthy, G. V., Jain, N. L., and Bhatia, B. S., 1960. Changes in physico-chemical composition of mangoes during ripening after picking, Food Sci. 9: 277. 
3. Official Methods of Analyses, 12th ed., 1975. Assn. Agri. Chem., Washington, D.C.

4. Pennock, W. and Maldonado, G., 1962. Hot water treatment of mango fruits to reduce anthracnose decay, J. Agr. Univ. P.R. 46: 272-83.

5. Soule, M. H., Jr. and Harding, P. C., 1957. Changes in physical characters and chemical constituents of Haden mangoes during ripening at $80^{\circ} \mathrm{F}$, Proc. Fla. State Hort. Soc. 69: 282.

6. Subramanyam, H., Krishnamurthy, S., and Parpia, H. A. B., 1975. Adv. Food Res. 21: 223. 